\title{
Historical overview of research on the tobacco mosaic virus genome: genome organization, infectivity and gene manipulation
}

\author{
Y. Okada
}

Department of Bioscience, Teikyo University, Utsunomiya, Japan

Early in the development of molecular biology, TMV RNA was widely used as a mitochondrial RNA that could be purified easily, and it contributed much to research on protein synthesis. Also, in the early stages of elucidation of the genetic code, artificially produced TMV mutants were widely used and provided the first proof that the genetic code was non-overlapping. In 1982, Goelet et al. determined the complete TMV RNA base sequence of 6395 nucleotides. The four genes $(130 \mathrm{~K}, 180 \mathrm{~K}, 30 \mathrm{~K}$ and coat protein) could then be mapped at precise locations in the TMV genome. Furthermore it had become clear, a little earlier, that genes located internally in the genome were expressed via subgenomic mRNAs. The initiation site for assembly of TMV particles was also determined.

However, although TMV contributed so much at the beginning of the development of molecular biology, its influence was replaced by that of Escherichia coli and its phages in the next phase. As recombinant DNA technology developed in the 1980s, RNA virus research became more detached from the frontier of molecular biology. To recover from this setback, a gene-manipulation system was needed for RNA viruses. In 1986, two such systems were developed for TMV, using full-length cDNA clones, by Dawson's group and by Okada's group. Thus, reverse genetics could be used to elucidate the basic functions of all proteins encoded by the TMV genome. Identification of the function of the $30 \mathrm{~K}$ protein was especially important because it was the first evidence that a plant virus possesses a cell-to-cell movement function. Many other plant viruses have since been found to encode comparable 'movement proteins'. TMV thus became the first plant virus for which structures and functions were known for all its genes. At the birth of molecular plant pathology, TMV became a leader again.

TMV has also played pioneering roles in many other fields. TMV was the first virus for which the amino acid sequence of the coat protein was determined and first virus for which cotranslational disassembly was demonstrated both in vivo and in vitro. It was the first virus for which activation of a resistance gene in a host plant was related to the molecular specificity of a product of a viral gene. Also, in the field of plant biotechnology, TMV vectors are among the most promising. Thus, for the 100 years since Beijerinck's work, TMV research has consistently played a leading role in opening up new areas of study, not only in plant pathology, but also in virology, biochemistry, molecular biology, RNA genetics and biotechnology.

Keywords: tobacco mosaic virus; gene manipulation of TMV; RNA virus; infectious cDNA clone; TMV vector; movement protein

\section{GENOMIC NUCLEIC ACID OF TOBACCO MOSAIC VIRUS (TMV)}

(a) Ribonucleic acid in purified TMV particles

To isolate and purify a virus, it is necessary first to establish an experimental system for assaying the virus. Before 1929, there were few methods that could be used to measure TMV quantitatively, but the necrotic local lesion assay method, developed by Holmes (1929) using Nicotiana glutinosa, was the simplest and the most accurate method of its day. This method became an important aid for researchers attempting to purify TMV particles.

At about the same time, methods for isolating and purifying proteins had made progress, and Sumner (1926) succeeded in crystallizing purified urease. This triggered, in the early 1930s, a flurry of attempts by many researchers in various countries to isolate and purify plant viruses. At that time, various biochemical studies suggested that plant viruses might be proteins. For example, Stanley (1934) showed that the infectivity of TMV was largely destroyed by pepsin at a $\mathrm{pH}$ at which the virus was otherwise stable. This was followed by his purification of TMV by a method similar to that used for proteins, resulting in crystallized TMV preparations. These crystals were infectious in aqueous solution even at $10^{-9} \mathrm{~g} \mathrm{ml}^{-1}$. Stanley's (1935) chemical studies led him to conclude that TMV was an autocatalytic protein which required the presence of living cells for its production.

In the following year, however, Stanley's description of the chemical constitution of TMV had to be revised, when Bawden et al. (1936) reported that they had isolated liquid crystalline preparations of TMV from TMV-infected 
plants, and that these TMV preparations contained nucleic acid of the ribose type. Soon after, Stanley (1937) and Best (1937) both confirmed the nucleoprotein nature of TMV. At that time, however, they did not recognize that the RNA is the element essential for infectivity.

The discovery of the chemical components of TMV particles had a tremendous impact on biological science. It was a revolutionary idea to think of an infectious disease agent as a crystallizable material. Once the idea was accepted, however, investigations on the chemical and physical properties of viruses began in earnest.

\section{(b) Infectious TMV RNA and its reconstitution with TMV coat protein}

Until about 1948, most attention was focused on the protein part of viruses. Although it was known that enzymes, which carried out important biological functions in cells, were proteins, the function of the nucleic acid was not known. However, Markham \& Smith (1949) showed that purified turnip yellow mosaic virus preparations contained two classes of particles, one an infectious nucleoprotein and the other a non-infectious particle which apparently consisted of an identical protein but lacked RNA. This suggested that the viral RNA was essential for infectivity. Harris \& Knight (1952) reported that the C-terminal threonine of TMV coat protein (CP) could be removed by carboxypeptidase without altering the infectivity of the virus, and that inoculation with such dethreoninized TMV gave rise to normal TMV again possessing C-terminal threonine. This result supported the idea that the viral RNA, not the viral protein, controlled the specificity of the viral protein. These pioneering experiments were published in the same year that the well-known Hershey-Chase (1952) experiment was reported.

However, doubts as to whether the RNA in TMV was really a genetic material or not persisted until 1956. Fraenkel-Conrat \& Williams (1955) had shown that on incubating a solution containing a mixture of a noninfectious disassembled TMV protein and purified, apparently non-infectious, TMV RNA at neutral $\mathrm{pH}$, normal-looking infectious TMV particles were formed. This experiment made a big impact because it appeared that a 'living molecule' had been put together in vitro from 'non-living' constitutents. The next year, the pioneering experiments of Gierer \& Schramm (1956) demonstrated that the free TMV RNA alone was capable of initiating virus replication, and this result was confirmed by Fraenkel-Conrat (1956). Thus it became clear that the infectivity observed a year before in the TMV reconstitution experiment was a result of labile infectivity of TMV RNA being protected by the CP and not of the creation of infectivity.

Fraenkel-Conrat \& Singer (1957) began in vitro studies on reconstitution of the CP of common strain TMV and RNAs from other TMV strains, and Holoubeck (1962) further extended their studies. In these experiments, the reconstituted virus had the host range specificity characteristic of the virus from which the RNA was obtained.

Many years after the first reconstitution of TMV, studies on its mechanism were taken up in laboratories in England, France and Japan (Butler \& Klug 1971; Lebeurier et al. 1977; Otsuki et al. 1977).

\section{TMV MUTANTS AND THE GENETIC CODE}

By 1966, the genetic code was known in almost full detail (Crick 1966). Much of this knowledge came from in vitro studies using synthetic polyribonucleotides of known composition and sequence as messenger RNA in various cell-free translation systems of Escherichia coli. However, to prove that the postulated genetic code was correct in living cells as well, it was necessary to perform experiments with proteins synthesized in vivo. For such experiments, the GP of plant viruses was useful.

Gierer \& Mundry (1958) first demonstrated the high efficiency of nitrous acid as an in vitro mutagen for TMV RNA. The mutagenic action was considered to be through deamination of cytosine to give uracil and deamination of adenine to give hypoxanthine, which behaved chemically like guanine. Nitrous acid produced many TMV mutants with altered biological characteristics. Hundreds of TMV mutants were prepared at Berkeley, Tübingen and elsewhere to analyse the amino acid constitution of the CP of the TMV mutants and determine the amino acid replacements (Tsugita \& Fraenkel-Conrat 1960, 1962; Funatsu \& Fraenkel-Conrat 1964; Wittmann \& Wittmann-Liebold 1966). Almost all the amino acid exchanges thus observed could be explained by the transition $\mathrm{A} \rightarrow \mathrm{G}$ or $\mathrm{G} \rightarrow \mathrm{U}$ in a single codon in the TMV CP gene. This would not have been possible if the codes postulated from in vitro studies were incorrect in vivo, or if the codes were not universal among bacterial and plant cells. Furthermore, it was observed that only one amino acid residue was replaced in most of the mutants and that, when two residues were changed, they were not neighbours, thus providing the first direct proof of the long-held assumption that the genetic code is non-overlapping. These experiments made an important contribution to our understanding of the genetic code.

\section{PRIMARY STRUCTURE OF TMV RNA AND GENOME ORGANIZATION}

\section{(a) Terminal sequences of TMV RNA}

TMV RNA was the first pure RNA molecule that became available for various studies. Therefore, methods for determining end-groups and terminal sequences were developed using TMV RNA. Sugiyama \& FraenkelConrat (1961) determined that the 3'-end of TMV RNA was an unphosphorylated adenosine, a result confirmed by Stein-Schneider \& Fraenkel-Conrat (1966). A little later, the 3 '-end sequence of about 70 nucleotides was established for several strains of TMV (Guilley et al. 1975; Lamy et al. 1975).

It was believed for a long time that the $5^{\prime}$-end of TMV RNA was also an unphosphorylated adenosine (Sugiyama \& Fraenkel-Conrat 1963). Later, however, the presence of a typical $5^{\prime}$-terminal cap structure $\left(\mathrm{m}^{7} \mathrm{GpppG}\right)$ was discovered in TMV RNA, although, unlike eukaryotic cellular mRNAs, the one or two bases adjacent to the $\mathrm{m}^{7} \mathrm{GpppG}$ in TMV RNA were not methylated (Zimmern 1975; Keith \& Fraenkel-Conrat 1975). The infectivity of TMV RNA was lost on removal of the cap structure by tobacco phosphodiesterase (Ohno et al. 1976). Mandeles (1968) isolated several unique oligonucleotides from ribonuclease $\mathrm{Tl}$ digests of TMV RNA. The largest of 


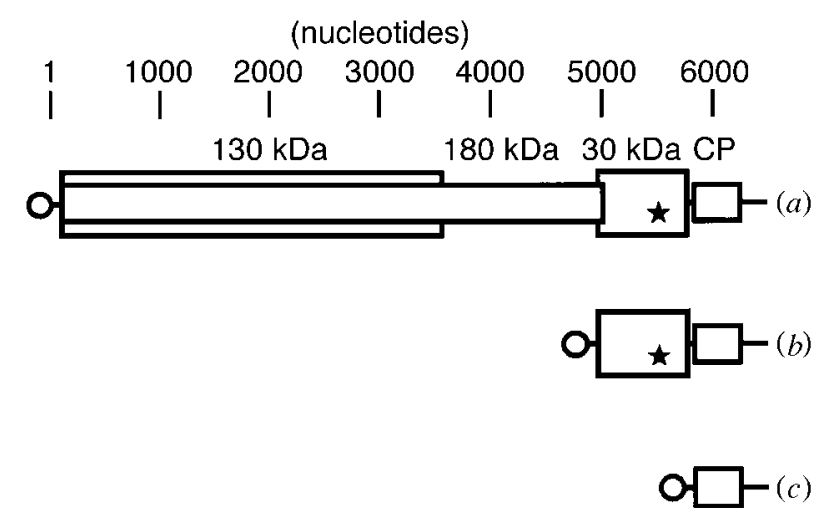

Figure 1. Schematic representation of the organization of the genomic and subgenomic RNAs of the common strain of TMV. (a) Genomic RNA; (b) subgenomic RNA for the 30K protein; (c) subgenomic RNA for the coat protein. Coding and non-coding regions are shown by boxes and lines, respectively. Circles represent the cap structure at the $5^{\prime}$-end. Stars denote the assembly origin.

these was estimated to be about 70 nucleotides long and lacked $\mathrm{G}$. The location of this sequence, called $\Omega$, was first thought to be near the $3^{\prime}$-end, but later it was found to be the $5^{\prime}$-terminal sequence (Richards et al. 1978).

\section{(b) Base sequence determination by RNA sequencing methods}

Although many methods were introduced to determine the base sequence of RNA, earlier analysis was restricted to oligonucleotides obtained after complete or partial digestion of RNA with several ribonucleases. Information obtained in this way was far from being the complete sequence of RNA. One drawback was the difficulty in obtaining pure RNA subfragments spanning the entire region of interest. Guilley et al. (1979) solved this problem using RNA from partially stripped TMV. TMV virions disassemble in a polar fashion from the end of the particle containing the $5^{\prime}$-end of the RNA when treated with mild alkali (Perham \& Wilson 1976). After nuclease treatment, various discrete size classes of partially stripped rods can be isolated. The RNA in the shortest and most abundant class of rods was approximately 1000 nucleotides in length. Using this RNA, the sequence of the 1000 nucleotides at the 3'-end of TMV RNA was reported (Guilley et al. 1979). This provided the base sequence of the CP cistron and predicted that the left-hand portion of the CP cistron was adjacent to the cistron for the $30 \mathrm{~K}$ protein, separated only by two non-translated nucleotides. This experiment was the first report on the partial genome organization of plant viruses based on nucleotide sequence analysis. However, such RNA sequencing methods still did not provide enough sequence information to reveal the precise genome organization of the remaining parts of TMV RNA.

\section{(c) Base sequence determination by cDNA sequencing}

In 1970, reverse transcriptase was discovered by Baltimore (1970) and Temin \& Mizutani (1970). They showed that RNA could act as the template for transcription of DNA, and opened a way for cloning RNA as cDNA. Furthermore, at about the same time, restriction enzymes were isolated and characterized, so enabling large DNA molecules to be manipulated (Smith \& Wilcox 1970). Thus, a little later, new methods for sequencing DNA were developed by Maxam \& Gilbert (1977) and Sanger et al. (1977). Advances in DNA sequencing techniques had given us the unprecedented ability to determine rapidly the nucleotide sequence of entire virus genomes. Particularly, as sequencing DNA is much easier than RNA, sequencing of cloned cDNAs of RNA genes opened a new era in elucidating genome organization of plant RNA viruses.

For TMV, the 3'-terminal 4000 nucleotides of common strain RNA and 1700 nucleotides of cowpea strain RNA were first successfully cloned as cDNAs and sequenced by Meshi et al. $(1981,1982 b)$. Soon after, the sequence of about 2000 nucleotides at the $3^{\prime}$-end of the RNA were determined and compared for several tobamovirus strains (Takamatsu et al. 1983). For plant viruses, this gave the first classification based on genome structure.

\section{(d) Genome organization of tobamoviruses}

In 1982, the entire sequence of 6395 nucleotides of the TMV (vulgare) genome was completed by Goelet et al. (1982). Their sequencing strategy involved cloning TMV cDNA fragments into bacteriophage M13 and sequencing each, then connecting the fragments by finding, with the aid of a computer, short overlapping stretches of nucleotides to piece together the whole sequence. Meanwhile, proteins approximately corresponding in size to the $130 \mathrm{~K}$ and $180 \mathrm{~K}$ proteins had already been found in infected tobacco leaves (Scalla et al. 1976) and in infected protoplasts (Sakai \& Takebe 1974). Besides these, the 30K protein had also been detected in both infected tobacco protoplasts (Beier et al. 1980) and leaves (Joshi et al. 1983). Goelet et al. (1982) were able precisely to locate the corresponding cistrons and the CP cistron on the genome (figure 1).

The cap structure is attached to the first nucleotide. This is followed in the vulgare strain by an untranslated leader sequence of 68 nucleotides. The long G-deficient stretch called $\Omega$, extends to the first AUG in this region. After the leader comes an ORF that encodes the $130 \mathrm{~K}$ protein. The termination codon for the $130 \mathrm{~K}$ protein is leaky and the read-through protein is of about $180 \mathrm{~K}$. The exact molecular weights are $126 \mathrm{~K}$ and $183 \mathrm{~K}$ but, as the proteins from different strains of TMV have slightly different numbers of amino acid residues (figure 2), their molecular weights will be slightly different. Therefore, for simplicity, the convention that rounds off the molecular weights to $130 \mathrm{~K}$ and $180 \mathrm{~K}$ is adopted here.

The 3 -terminal five codons of the $180 \mathrm{~K}$ protein gene overlap with the third ORF, coding for the $30 \mathrm{~K}$ protein. This third ORF terminates two nucleotides before the initiation codon of the fourth ORF, which encodes the $17 \mathrm{~K} \mathrm{CP}$ and is located closest to the $3^{\prime}$ terminus. Later, another ORF for a $54 \mathrm{~K}$ protein was postulated to exist in-frame in the read-through region of the $180 \mathrm{~K}$ protein (Sulzinski et al. 1985), but this protein has not been detected in vivo (Saito et al. 1986). Therefore, it is concluded that the TMV genome codes for four gene products. The untranslated 3 '-terminal sequence consists of 204 nucleotides. This arrangement, summarized 


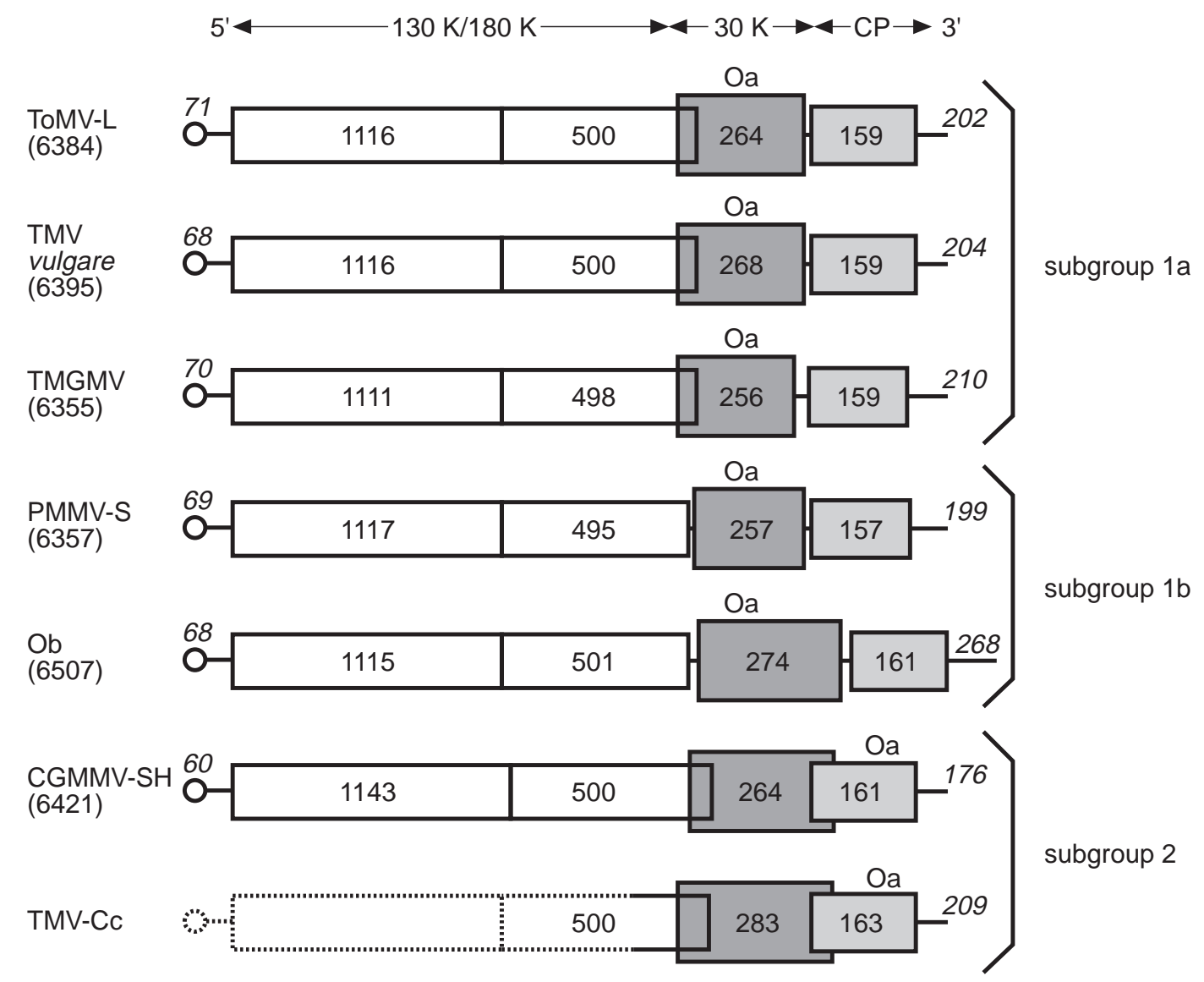

Figure 2. Genome organization of various tobamoviruses (Ikeda et al. 1993). Each coding region is shown by a box in which its amino acid length is indicated. Horizontal lines represent $5^{\prime}$ and $3^{\prime}$ non-coding regions with their nucleotide lengths given in italics. The total nucleotide length of each genome is shown in parenthesis below the name of the strain. Oa indicates the predicted position of the assembly origin in each genome. The vertical lines (inside left-hand boxes) indicate the positions of readthrough of the $130 \mathrm{~K}$ protein gene. The region shown by dotted lines in TMV-Cc has not been sequenced.

schematically in figure 1, was the first example of a totally sequenced genome and the genetic map for a plant RNA virus.

Two years later, the complete base sequence of the RNA genome of TMV-L (tomato mosaic virus strain, ToMV) was determined (Ohno et al. 1984). Among viruses in the tobamovirus group, ToMV is the only one that can produce necrotic local lesions on tobacco plants with the $\mathcal{N}^{\prime}$ gene. Furthermore, TMV-L $\mathrm{L}_{11} \mathrm{~A}$, which is an attenuated strain derived from TMV-L, has been widely used in Japan to prevent TMV infection by cross-protection. We therefore thought the best strain for elucidating plant-virus interactions at the molecular level would be TMV-L. Later, gene engineering systems for TMV-vulgare (Dawson et al. 1986) and TMV-L (Meshi et al. 1986) were established and these two strains became the centre of TMV genome research.

In addition to the vulgare and $\mathrm{L}$ strains, the complete nucleotide sequences of the RNA of several other tobamoviruses are now known: $\mathrm{M}$ strain (an attenuated strain closely related to common strain, U1; Holt et al. 1990); a few tomato mosaic virus strains including $\mathrm{L}_{11} \mathrm{~A}$ (an attenuated strain) (Nishiguchi et al. 1985), Ltal and Ltbl (resistance-breaking strains overcoming Tm-1 and Tm-2 resistance, respectively; Meshi et al. 1988, 1989); tobacco mild green mosaic virus (TMGMV; Solis \& Garcia-
Arenal 1990); cucumber green mottle mosaic virus (CGMMV SH strain; Ugaki et al. 1991); pepper mild mottle virus (PMMV strains including S (Alonso et al. 1991) and J (Kirita et al. 1997); tobamovirus Ob (Padgett \& Beachy 1993; Ikeda et al. 1993); rakkyo strain (Chen et al. 1996); and a few crucifer-infecting tobamoviruses, including turnip vein clearing virus (Lartey et al. 1994), cr-TMV (Dorokhov et al. 1994), chinese rape mosaic virus (Aguilar et al. 1996) and TMV-Cg (Yamanaka et al. 1998).

Several variant types of genome organization were observed among tobamoviruses. Ikeda et al. (1993) classified those tobamoviruses for which the sequences were completely determined into three subgroups, as shown in figure 2. TMV vulgare, TMV-L and TMGMV have genome structures in which only the $180 \mathrm{~K}$ and the $30 \mathrm{~K}$ ORFs overlap. In the genomes of $\mathrm{Ob}$ and PMMV-S, there are no overlaps between any adjacent ORFs. In contrast, all adjacent ORFs overlap in the CGMMV-SH and TMV-Ge genomes.

Goelet et al. (1982) reported that the 5'-terminal sequence of TMV vulgare occurred as two variants, a shorter and a longer one. However, Meshi et al. (1983a) showed that the longer variant was not vulgare, but that it came from a contaminating tomato strain. Dawson et al. (1986) confirmed that the 5'-region of TMV RNA is not polymorphic. 


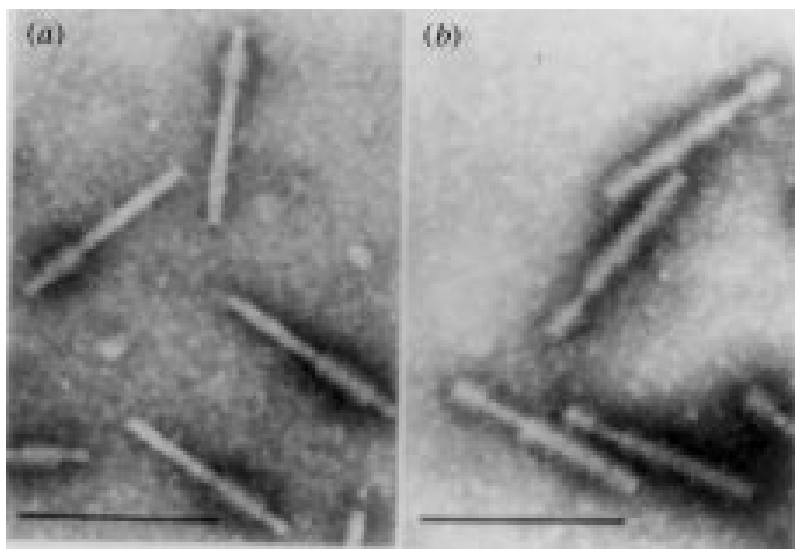

Figure 3. TMV particles after sequential reconstitution from TMV RNA, first with TMV coat protein $(\mathrm{CP})$ and then with ToMV CP. Reconstituted particles were treated with a specific antibody for $(a)$ TMV CP or a specific antibody for ToMV (b) CP. Bar represents $300 \mathrm{~nm}$.

\section{(e) Location of the assembly origin}

Since Fraenkel-Conrat \& Williams (1955) showed that TMV CP and TMV RNA can assemble in vitro to form intact virus particles, many researchers have studied the mechanism of assembly of the TMV rod as a model of macromolecular assembly from protein and RNA. For a long time, it was believed that assembly started at the 5'end of TMV-RNA (Butler \& Klug 1971; Ohno et al. 1971). However, this view became doubtful after the finding that the $5^{\prime}$-end of TMV RNA is blocked by the cap structure. Zimmern \& Wilson (1976) first located the assembly origin between 900 and 1300 nucleotides from the 3 '-end of the RNA. In the following year, by examining many partially reconstituted particles with an electron microscope and by determining the lengths of naked RNAs which were not incorporated into the particle, Lebeurier et al. (1977) determined the exact location of the assembly origin.

In the same year, we located the assembly origin by electron microscopic serology using strain specific antibodies (Otsuki et al. 1977). Common strain TMV RNA was sequentially reconstituted, first with a small amount of the CP of the common strain, and then with an excess of the CP of a tomato strain. The particles thus reconstituted were treated with antibody specific for each strain and then examined by electron microscopy to locate regions of the rod possessing each kind of CP (figure 3). By this means, the assembly origin was located at about 720 nucleotides from the $3^{\prime}$-end of TMV RNA.

Using this method, combined with base sequences, the nucleotide sequence of the assembly origins for common strain (Zimmern 1977; Jonard et al. 1977; Meshi et al. 1982a), tomato strain (Takamatsu et al. 1983), cowpea strain (Meshi et al. 1981) and cucumber green mottle mosaic (Meshi et al. 1983b) tobamoviruses were determined. All the assembly origins had a stable hairpin structure with the looped-out common target sequence, GAXGUUG (Okada 1986). Although internal initiation was the mechanism of TMV assembly for all tobamoviruses studied, the location of the assembly origin differed among strains. Depending on its location, Fukuda et al. (1981) classified several tobamoviruses into two subgroups, one subgroup having the assembly origin within the $30 \mathrm{~K}$ protein cistron and the other within the CP cistron (figure 2).

The confirmation that the assembly origin resides in the internal region of TMV RNA made it inevitable that particle assembly would proceed bidirectionally. Many studies on the mechanism of TMV assembly in vitro have been described, and there is a consensus about most of the details of the initial events, but the nature of the elongation process remains controversial (Butler 1984; Okada 1986). In contrast, there has not been much progress in research on TMV assembly in plant cells, but recently the first experiments were reported in which pseudovirus particles were self-assembled in E. coli (Hwang et al. 1994).

\section{FUNCTIONS OF VIRUS-CODED PROTEINS AND UNTRANSLATED REGIONS REVEALED BY GENETICALLY ENGINEERED INFECTIOUS TMV RNA}

\section{(a) In vitro transcription of TMV RNA from full-length cDNA clones}

Although, in 1982, the amino acid sequences of all TMV-coded proteins could be deduced from the nucleotide sequences, the functions of the proteins, other than the CP, were unclear. This is because it was still impossible to isolate the proteins from TMV-infected cells for further study. A solution to this problem was to establish a gene manipulation system by which reverse genetics could be applied. Despite the fact that, by that time, genetic engineering methods for DNA had been established and were used widely in molecular biology research, a system for RNA was lacking. Finally in 1984, Ahlquist et al. established an RNA manipulation system using brome mosaic virus (BMV) RNAs. They transcribed infectious BMV RNAs in vitro from full-length cDNA clones. Because genes could be manipulated in cDNA, genetically engineered RNAs were now obtainable. This success in manipulating BMV genes encouraged many plant-virus researchers, and the method was applied immediately to TMV.

Infectious TMV RNA has been synthesized successfully in vitro from full-length cDNA clones for the common strain (Dawson et al. 1986), and the tomato strain (figure 4) (Meshi et al. 1986). In the early experiments, infectious TMV RNA was transcribed by E. coli RNA polymerase under the direction of the $\mathrm{P}_{\mathrm{M}}$ promoter. Recently, however, many researchers have obtained infectious transcripts with T7 RNA polymerase (Holt \& Beachy 1991). Using in vitro transcripts equivalent to 0.2 to $0.5 \mu \mathrm{g}$ of authentic TMV RNA, $60-80 \%$ of protoplasts derived from suspension-cultured cells of tobacco could be infected by the electroporation method (Watanabe et al. 1987a).

Today, in vitro transcription has become a standard technique in genetic analysis of RNA genomes. Such a system makes it possible to manipulate genomic RNA by modifying biologically active cDNA clones by substitution, deletion or insertion of nucleotides. This has enabled the functions of many virus-coded proteins and untranslated regions to be elucidated by reverse genetics.

\section{(b) $130 \mathrm{~K}$ and $180 \mathrm{~K}$ proteins}

The $130 \mathrm{~K}$ and $180 \mathrm{~K}$ proteins were thought to be involved in viral RNA replication. For example, their 


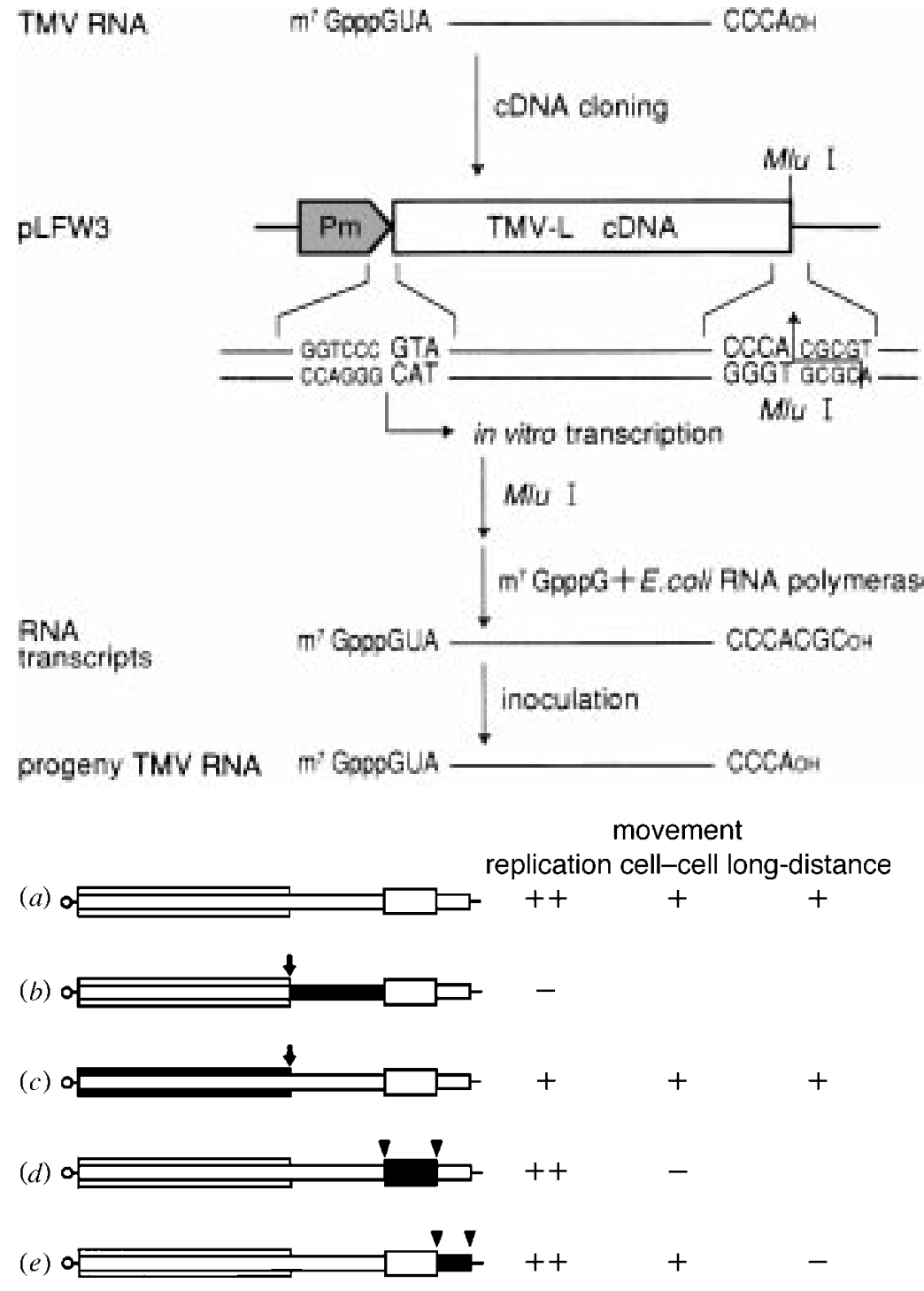

Figure 4. Schematic representation of the method for the in vitro synthesis of infectious TMV RNA.
Figure 5. Genetically engineered TMV mutants and their characteristics. The dark areas indicate genes which lost their functions either by base substitution or deletion. (a) TMV wild type; (b) TMV mutant which produces $130 \mathrm{~K}$ protein but not $180 \mathrm{~K}$ protein; $(c)$ TMV mutant which produces $180 \mathrm{~K}$ protein but not $130 \mathrm{~K}$ protein; (d) TMV mutant lacking the $30 \mathrm{~K}$ protein gene;

(e) TMV mutant lacking the coat protein gene. amino acid sequences have significant homology with known RNA-dependent RNA polymerases (Kamer \& Argos 1984; Haseloff et al. 1984). The most convincing evidence that both the $130 \mathrm{~K}$ and $180 \mathrm{~K}$ proteins are essential components of the RNA replicase complex was given by a mutant, constructed by Meshi et al. (1987), where both the $30 \mathrm{~K}$ and CP genes were deleted. The mutant replicated in tobacco protoplasts. The time-course of synthesis of progeny viral RNA molecules did not differ significantly from that of wild-type TMV RNA. It was also suggested that the $130 \mathrm{~K}$ and $180 \mathrm{~K}$ proteins were involved in synthesis the $30 \mathrm{~K}$ protein subgenomic mRNA (Watanabe et al. 1987b).

Ishikawa et al. (1986) constructed TMV mutants that had several kinds of mutations at or near the amber termination codon of $130 \mathrm{~K}$ protein gene. Mutants that did not produce the $180 \mathrm{~K}$ protein were not infectious (figure $5 b$ ), but mutants that produced the $180 \mathrm{~K}$ protein but not the $130 \mathrm{~K}$ protein (figure $5 c$ ) retained infectivity although their specific activity was low. Therefore, a balanced expression of the $130 \mathrm{~K}$ and $180 \mathrm{~K}$ proteins seems to be necessary for efficient replication of TMV RNA. Recently, Hamamoto et al. (1997) reported that a single amino acid substitution (Glu 979 to Ile) in the $130 \mathrm{~K}$ and $180 \mathrm{~K}$ proteins of ToMV alters host specificity.
For a long time, the molecular constituents of the TMV replicase complex were not established. Recently, however, Osman \& Buck (1997) isolated the TMV RNA polymerase complex. The purified RNA polymerase preparation contained viral $130 \mathrm{~K}$ and $180 \mathrm{~K}$ proteins, together with a host $56 \mathrm{~K}$ protein which is related to the RNA-binding subunits of yeast eIF-3.

\section{(c) $30 K$ protein}

Early genetic studies with $t$ mutants demonstrated the existence of a virus-coded function required for cell-tocell movement of TMV (Taliansky et al. 1982). A TMV ts mutant for cell-to-cell movement (Lsl) has greatly contributed to the understanding of this virus-coded function. At $32^{\circ} \mathrm{C}$, Lsl can replicate and assemble normally in leaf cells infected by inoculation, or in protoplasts, but cannot spread from cell to cell in leaves (figure 6), whereas it spreads normally at $20^{\circ} \mathrm{C}$ (Nishiguchi et al. 1978). Ohno et al. (1983) showed that the mutation leading to this $t s$ state was a serine to proline change at position 154 in the $30 \mathrm{~K}$ protein.

The role of the $30 \mathrm{~K}$ protein was further demonstrated directly by two other kinds of experiment. First, transgenic tobacco that expresses wild-type $30 \mathrm{~K}$ protein complements the Ls1 mutant and allows it to spread from 
cell to cell and systemically at non-permissive temperatures (Deom et al. 1987). Second, various frameshift mutations in the $30 \mathrm{~K}$ gene gave a defective phenotype for cell-to-cell movement of TMV (figure $5 d$ ) (Meshi et al. 1987). The $30 \mathrm{~K}$ protein is now called the 'movement protein' (MP).

Tomenius et al. (1987) found that MP accumulates in plasmodesmata of TMV-infected tissues. Moreover, Wolf et al. (1989) found that the molecular size exclusion limit of $\mathrm{MP}(+)$ transgenic tobacco for cell-to-cell transport was about tenfold greater than that of control tobacco. Another property of MP was reported by Citovsky et al. (1990) who showed that it binds in vitro to single-stranded nucleic acids to form an elongated structure of $1.5-2.0 \mathrm{~nm}$ diameter (Citovsky et al. 1992). The diameter of the RNA-MP complex was similar to the size of molecules that could pass through the modified plasmodesmata. These observations led to the proposal that tobamovirus genomic RNA forms a complex with MP and passes through the plasmodesmata, which are enlarged by a second activity of MP, resulting in movement of genomic RNA to adjacent cells. Recently, Heinlein et al. (1995) and McLean et al. (1995) reported that MP is associated with microtubules in TMV-infected protoplasts. They presumed that the $\mathrm{MP}-$ microtubule association was a stage on the way to or from plasmodesmata. Watanabe $e t$ al. (1992) demonstrated that ToMV MP is phosphorylated in infected protoplasts, and Kawakami et al. (1998) determined that serine 37 and serine 238 in the MP are sites of phosphorylation.

On infecting tomato protoplasts with ToMV, Takahashi et al. (1998) observed a tubular structure on the surface of protoplasts somewhat resembling plasmodesmata (figure 7). These structures result from a function of the $30 \mathrm{~K}$ protein. There are several other reports that the MP of other plant viruses produced tubular structures similar to the above (Van Lent et al. 1991; Kasteel et al. 1997; Kikkert et al. 1997), but these contain virus particles. It may be that MP not only widens the paths of existing plasmodesmata, but also induces synthesis of new plasmodesmata.

In subsequent studies, MP has been discovered in almost all plant viruses examined. In the process of the evolution of plant viruses, the MP gene must have been acquired to enable them to pass through cell walls. The discovery of this function of the TMV $30 \mathrm{~K}$ protein was a starting point for attracting many researchers to plasmodesma research. Today, the elucidation of mechanisms of information transmission among cells through plasmodesmata has become a leading topic in plant science.

\section{(d) The coat protein $(\boldsymbol{C P})$}

The GP protects genomic RNA by forming a virus particle. However, reverse genetics experiments showed that the CP is multifunctional.

Some time ago it was observed that mutants with defective GP were not only unable to form virus particles but also unable to spread rapidly to non-inoculated leaves (Siegel et al. 1962). Thus, it was suggested that the CP was involved in long-distance virus movement. Takamatsu et al. (1987) constructed a TMV mutant, lacking the CP gene (figure $5 e$ ), which was apparently defective in systemic movement. Involvement of the CP in long- distance movement was further investigated by Saito et al. (1990), who made many kinds of mutation in the CP gene. No virus particles were produced in vivo by any mutant which had lost the ability to move long distances. Mutants which produced CP retained the ability to form virus particles in vivo, spread systemically and caused mosaic symptoms. These results suggested that the ability of TMV CP to assemble into virus particles is crucial for long-distance movement and that TMV particles may play a pivotal role in such movement.

Nicotiana species with the $\mathcal{N}^{\prime}$ gene react to the common strain of TMV with systemic mosaic disease, whereas ToMV produces necrotic local lesions. By constructing recombinants between these two virus strains, Saito et al. (1987) showed that the CP gene of ToMV encoded a factor responsible for induction of the hypersensitive response (HR) in plants with the $\mathcal{N}^{\prime}$ gene. Moreover, Knorr \& Dawson (1988) showed that a single point mutation in the CP gene of a common strain of TMV, accompanied by an amino acid change, gave an isolate which induced HR in $\mathcal{N}^{\prime}$ plants. Other studies with mutants, in which the GP gene was partially deleted, showed that CP could also influence symptoms in other ways (Dawson et al. 1988; Saito et al. 1989).

\section{(e) Untranslated regions}

TMV RNA has a non-coding region 68 nucleotides long at the $5^{\prime}$-end. A long G-deficient stretch here, called $\Omega$ (Mandeles 1968), is well conserved among several TMV strains. ToMV mutants which carry several deletions in this sequence were constructed and their multiplication was analysed (Takamatsu et al. 1991; Watanabe et al. 1996). Several mutants with deletions of about ten nucleotides retained the ability to replicate, but those with long deletions did not.

At the 3 -extremity of the $3^{\prime}$-terminal non-coding region of about 200 nucleotides, a tRNA-like structure can theoretically be folded (Pleij et al. 1985; Rietveld et al. 1984). The 3 '-end of the common strain RNA can be aminoacylated with His (Oberg \& Philipson 1972), whereas that of TMV-Cc can be aminoacylated with Val (Beachy et al. 1976). Preceding the tRNA-like structure, three consecutive pseudoknot structures are found in all TMV strains sequenced so far (Van Belkum et al. 1985; Garcia-Arenal 1988). When the hairpin structure in one pseudoknot was destabilized by base substitutions, infectivity was lost (Takamatsu et al. 1990).

\section{STRATEGY FOR TMV GENE EXPRESSION}

\section{(a) Expression of the $130 \mathrm{~K}$ and $180 \mathrm{~K}$ protein genes}

The genome of TMV encodes at least three nonstructural proteins and the CP (figure 1). The genomic RNA has been translated in several cell-free systems. In reticulocyte lysates (Knowland et al. 1975; Pelham \& Jackson 1976) and in wheat germ extract (Bruening et al. 1976), only the two large $130 \mathrm{~K}$ and $180 \mathrm{~K}$ proteins, encoded near the $5^{\prime}$-end of the genomic RNA, were translated. Synthesis of the $130 \mathrm{~K}$ protein predominates over that of $180 \mathrm{~K}$ protein. Pelham (1978) showed that the synthesis of these two proteins was initiated at the same site, and that the $180 \mathrm{~K}$ protein was generated by read-through of the termination codon of the $130 \mathrm{~K}$ 


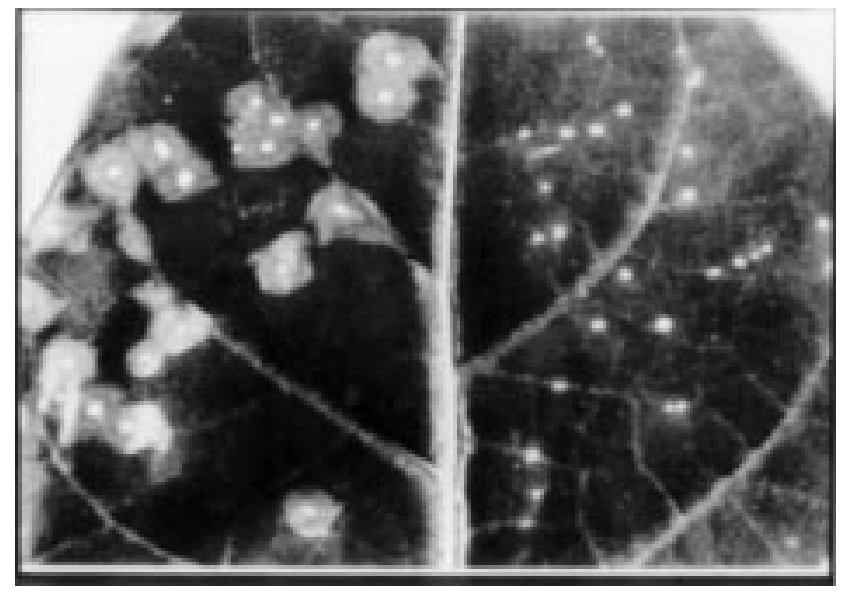

Figure 6. Temperature shift treatment for tobacco half-leaves inoculated with TMV-L or with TMV-Lsl. Necrotic lesions were photographed after treating the infected leaf first at $22^{\circ} \mathrm{C}$ for 3 days, then at $32^{\circ} \mathrm{C}$ for 2 days, and finally at $22^{\circ} \mathrm{C}$ for 1 day. In the area surrounding the necrotic lesions, a collapsed area appeared for TMV-L (left), but not for TMV-Ls1 (right).

protein gene. The genes located internally in the genome are not expressed from the genomic RNA, but from subgenomic RNAs which are generated during the course of replication (Beachy et al. 1976; Hunter et al. 1976; Palukaitis et al. 1983; Sulzinski et al. 1985).

\section{(b) Expression of the coat protein gene}

Initially Tsugita et al. (1962) reported that TMV CP was synthesized under the direction of genomic RNA in a cell-free, protein-synthesizing E. coli system. However, a more thorough investigation later revealed that the product synthesized was not a TMV protein (Aach et al. 1964; Schwartz 1967). After this revelation, many researchers attempted to produce the CP using genomic RNA in cell-free translation systems: the $E$. coli system (Schwartz 1967), wheat germ system (Hunter et al. 1976; Efron \& Marcus 1973) and amphibian oocyte system (Knowland 1974). However, all attempts failed and it was concluded that TMV genomic RNA was not an efficient template for CP gene translation.

TMV-induced RNAs smaller than genomic RNA had been found in TMV-infected tobacco tissues and protoplasts, and named LMC-RNA (Jackson et al. 1972). This LMC-RNA was shown to be associated with polyribosomes from infected cells, which suggested that it was directly translated in vivo (Beachy \& Zaitlin 1975). Indeed, in several cell-free systems, LMC-RNA (MW $0.25 \times 10^{6}$ ) isolated from infected plants could be translated in vitro to produce a protein indistinguishable from the authentic CP (Knowland et al. 1975; Hunter et al. 1976; Siegel et al. 1976). Thus, LMC-RNA was confirmed as the subgenomic mRNA for TMV CP (figure 1). The 5 '-end of the LMC-RNA is located at residue 693 from the $3^{\prime}$-terminus of the genomic RNA (Browning \& Clark 1980; Guilley et al. 1979). LMC-RNA was shown to be capped at the 5'end, just as is the genomic RNA (Zimmern 1975; Keith \& Fraenkel-Conrat 1975).

LMC-RNA was absent from RNA extracted from virions of the U1 and U2 strains of TMV (Skotnicki et al. 1976; Beachy \& Zaitlin 1977). However, the cowpea (Cc)

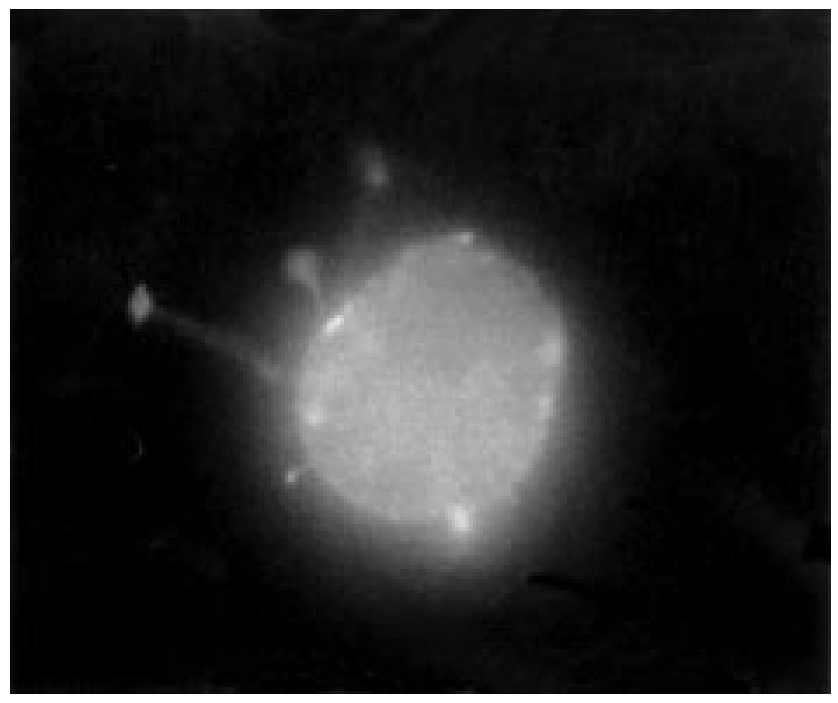

Figure 7. Tubular structures on the surface of a tomato protoplast infected with ToMV carrying a MP-GFP fusion protein gene. Observed under a fluorescence microscope at $18 \mathrm{~h}$ after inoculation.

strain produced, in addition to the normal-length TMV rods, other shorter rods containing the CP messenger RNA (Bruening et al. 1976; Higgins et al. 1976). Later it was shown that cucumber green mottle mosaic tobamovirus, watermelon strain (CGMMV-W) also contained such short rods (Fukuda et al. 1981). This is because the particle assembly origin of the Cc and CGMMV-W strains is located in the CP cistron (Fukuda et al. 1981).

\section{(c) Expression of the $30 \mathrm{~K}$ protein gene}

The RNA isolated from purified TMV particles contains, in addition to the full-length genomic RNA, a heterogeneous population of molecules with molecular weights in the range between $0.6 \times 10^{6}$ and $1.6 \times 10^{6}$. Among these, an RNA of discrete size and molecular weight about $0.68 \times 10^{6}$ was termed intermediate-length RNA-2 ( $\mathrm{I}_{2}$-RNA), and that with molecular weights $0.9-1.6 \times 10^{6}$ was called $\mathrm{I}_{1}$-RNA (Beachy \& Zaitlin 1977). These RNAs are derived from the 3 '-end of the genomic RNA.

$\mathrm{I}_{2}$-RNA, isolated from infected tissues, was translated in vitro into the $30 \mathrm{~K}$ protein (Beachy \& Zaitlin 1977). Thus, $\mathrm{I}_{2}$-RNA was confirmed to be the subgenomic mRNA for the $30 \mathrm{~K}$ protein (figure 1). The $5^{\prime}$-end structure of $\mathrm{I}_{2}$-RNA is still controversial (Joshi et al. 1983; Hunter et al. 1983; Beachy \& Zaitlin 1977; Watanabe et al. $1984 b$ ). The initiation site for transcription of the $30 \mathrm{~K}$ protein mRNA was mapped at residue 1558 from the 3'terminus of genomic RNA (Watanabe et al. 1984b; Meshi et al. 1982a). Moreover, homology exists between the sequences around the capping site of the CP mRNA and of the $30 \mathrm{~K}$ protein mRNA. These homologous areas may represent the promoter for subgenomic RNA synthesis by the viral RNA polymerase (Watanabe et al. 1984b).

The $30 \mathrm{~K}$ protein is expressed early and transiently in infection, whereas the CP is expressed later and persistently (Watanabe et al. 1984a). However, when under the control of the CP subgenomic promoter in a recombinant isolate, expression of the $30 \mathrm{~K}$ protein became late (Lehto 


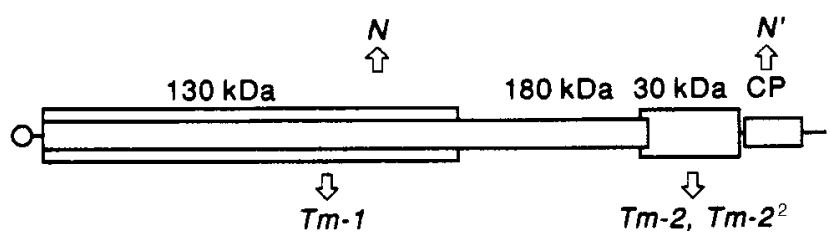

Figure 8. Relationship between host resistance genes and the TMV-coded proteins which activate them.

et al. 1990). This result suggests that the promoter sequence controls the timing of expression.

\section{(d) Other proteins}

In TMV-infected plants, Goelet \& Karn (1982) detected many mRNA species which had the same 3'terminal sequence as, and hybridized to, cDNA of TMVRNA. Also, Sulzinski et al. (1985) reported that the $54 \mathrm{~K}$ protein, corresponding to the $\mathrm{C}$-terminal portion of the $180 \mathrm{~K}$ protein, was translated from $\mathrm{I}_{1}$-RNA. However, in TMV-infected protoplasts, the genomic RNA, the $30 \mathrm{~K}$ protein mRNA $\left(\mathrm{I}_{2}\right)$ and the coat protein mRNA (LMC) were detected but $\mathrm{I}_{1}$-RNA (Watanabe et al. 1984a) and the $54 \mathrm{~K}$ protein were not (Saito et al. 1986). Therefore, only the $130 \mathrm{~K}, 180 \mathrm{~K}, 30 \mathrm{~K}$ and CPs are expected to play a role in the replication of TMV.

\section{(e) Uncoating of TMV RNA after inoculation}

For TMV to express its genes after infecting plant cells, the genomic RNA has to be uncoated and made available for translation. Wilson (1984) proposed a cotranslational disassembly hypothesis based on results of experiments in vitro. This predicts that CP subunits are released first from the 5 '-end of the TMV rod, that ribosomes bind to the exposed part of the RNA and that translation of the first ORF then begins. As the translation progresses, additional CP subunits are released. Mundry et al. (1991) have confirmed that the non-coding region at the $5^{\prime}$-end of TMV RNA is uncoated rapidly at the initial stage of translation.

The occurrence of cotranslational disassembly in vivo was reported by Shaw et al. (1986). Furthermore, Wu et al. (1994) showed, using protoplasts, that within the first 3 min of inoculation, a region of at least 4635 nucleotides from the $5^{\prime}$-end was disassembled. This represents about $72 \%$ of the TMV particle and roughly equates to the entire $180 \mathrm{~K}$ protein ORF (78\% of the TMV particle).

\section{RELATIONSHIP BETWEEN HOST RESISTANCE GENES AND TMV-ENCODED PROTEINS}

The resistance genes, $T m-1, T m-2$ and $T m-2^{2}$, have been identified in tomato and are used in practice to protect tomato plants from TMV infection. In tomato plants with the Tm-1 gene, multiplication of TMV is inhibited. Meshi et al. (1988) examined the nucleotide sequence of TMV Ltal, which is a spontaneous resistance-breaking mutant derived from TMV L. They found two amino acid substitutions in the $130 \mathrm{~K}$ and $180 \mathrm{~K}$ proteins. Therefore, the $130 \mathrm{~K}$ and $180 \mathrm{~K}$ proteins may be involved in interaction with the putative $T m-1$ gene product.

The resistance genes, $T m-2$ and $T m-2^{2}$, are expressed only in intact tissues. Wild-type TMV can multiply in

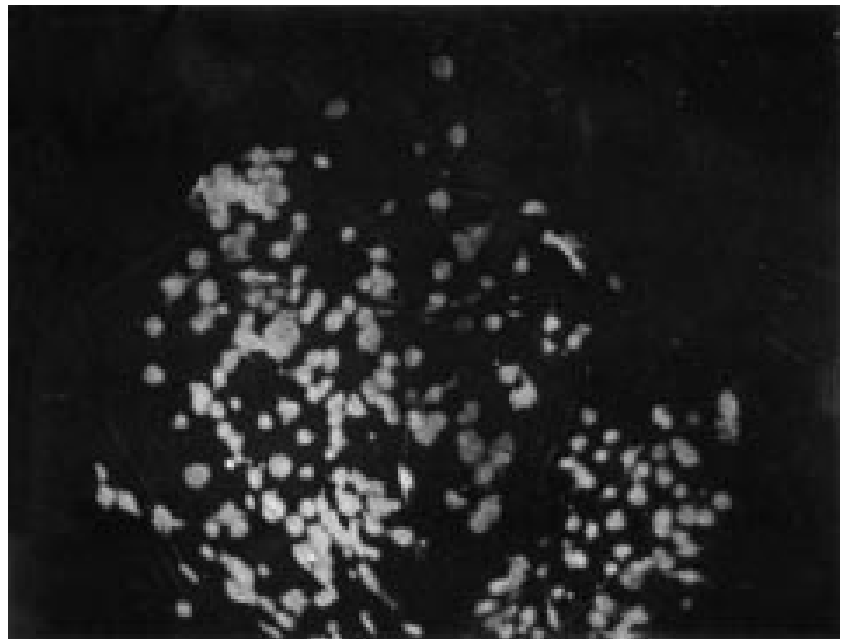

Figure 9. Fluorescence emitted, under UV light, from a tobacco leaf which was infected with TMV whose CP gene was replaced by a GFP gene (seven days after inoculation). The virus spreads from cell to cell only.

protoplasts isolated from tomato plants with either of these genes. Thus these resistance genes operate at the level of cell-to-cell movement. A resistance-breaking strain, TMV Ltbl, which is able to spread systemically in tomato plants that have the $\mathrm{Tm}$-2 gene, has two amino acid changes in the $30 \mathrm{~K}$ protein compared with that of the parental isolate (Meshi et al. 1989). Similarly, a resistance-breaking strain that can invade tomato plants that have the $T m-2^{2}$ gene also had two amino acids in the $30 \mathrm{~K}$ protein that were changed from those in the parent virus (Weber et al. 1993). The $30 \mathrm{~K}$ protein may therefore interact with the $T m-2$ and $T m-2^{2}$ gene products to prevent viral cell-to-cell movement.

Almost all tobamoviruses cause $\mathrm{HR}$ in tobacco plants carrying the $\mathcal{N}$ gene but a tobamovirus uniquely capable of overcoming this resistance has been isolated and designated ToMV Ob (Tobias et al. 1982; Csillery et al. 1983). Padgett \& Beachy (1993) analysed a chemically induced mutant of the cloned $\mathrm{Ob}$ virus that induces local lesions on tobacco with the $\mathcal{N}$ gene. They found that the mutant contained a single amino acid change in the $130 \mathrm{~K}$ protein, suggesting that the $130 \mathrm{~K}$ protein is required for HR induction in tobacco with the $\mathcal{N}$ gene. Recently, the $\mathcal{N}$ gene was isolated by Whitham et al. (1994). The mechanism of how the $\mathcal{N}$ gene induces $\mathrm{HR}$ in tobacco plants by interacting with the $130 \mathrm{~K}$ protein at the molecular level will doubtless be clarified in the near future.

The relations between TMV encoded proteins and resistance genes in plants are summarized in figure 8. Clearly, plants have evolved diverse mechanisms for preventing TMV infection and invasion of tissues.

\section{TMV AS A GENE VECTOR}

With the establishment of a genetic engineering system for TMV, it became possible to insert foreign genes into the viral genome and thus to develop TMV as a gene vector. For example, the CP gene could be replaced with the chloramphenicol acetyl transferase (CAT) gene (Takamatsu et al. 1987). Alternatively, insertion of a gene 
for the jellyfish fluorescent protein, GFP, gives a TMV isolate that emits fluorescence under UV illumination, enabling spread of the virus in tissues to be observed (figure 9). However, TMV vectors in which the CP gene is replaced with another gene can multiply only in inoculated leaves.

More recently, many otherTMV vectors, which retain the CP gene intact and can infect systemically, have been developed in many research laboratories. These newly developed vectors include those used to express $\alpha$-trichosanthin (Kumagai et al. 1993), various animal virus epitopes (Hamamoto et al. 1993; Sugiyama et al. 1995), a malarial epitope (Turpen et al. 1995) and so on. Recent developments of this kind are summarized by Turpen.

I would like to thank numerous of my staff and students for their many achievements over the years when we were working together on the TMV genome at the University of Tokyo.

\section{REFERENCES}

Aach, H. G., Funatsu, G., Nirenberg, M. W. \& Fraenkel-Conrat, H. 1964 Further attempts to characterise products of TMVRNA-directed protein synthesis. Biochemistry 3, 1362-1366.

Aguilar, I., Sanchez, F., Martin, M. A., Martinez-Herrera, D. \& Ponz, F. 1996 Nucleotide sequence of chinese rape mosaic virus (oilseed rape mosaic virus), a crucifer tobamovirus infectious on Arabidopsis thaliana. Plant Mol. Biol. 30, 191-197.

Ahlquist, P., French, R., Janda, M. \& Loesch-Fries, L. S. 1984 Multicomponent RNA plant virus infection derived from cloned viral cDNA. Proc. Natl Acad. Sci. USA 81, 7066-7070.

Alonso, E., Garcia-Luque, I., De La Cruz, A., Wicke, A., AvilaRincon, M. J., Serra, M. T., Castresana, C. \& Diaz-Ruiz, J. R. 1991 Nucleotide sequence of the genomic RNA of pepper mild mosaic virus, a resistance-breaking tobamovirus in pepper. 7. Gen. Virol. 72, 2875-2884.

Baltimore, D. 1970 Viral RNA-dependent DNA polymerase. Nature 226, 1209-1211.

Bawden, F. C., Pirie, N. W., Bernal, J. D. \& Fankuchen, I. 1936 Liquid crystalline substances from virus-infected plants. Nature 138, 1051-1052.

Beachy, R. N. \& Zaitlin, M. 1975 Replication of tobacco mosaic virus. VI. Replicative intermediate and TMV-RNA related RNAs associated with polyribosomes. Virology 63, 84-97.

Beachy, R. N. \& Zaitlin, M. 1977 Characterization and in vitro translation of the RNAs from less-than-full-length, virusrelated, nucleoprotein rods present in tobacco mosaic virus preparations. Virology 81, 160-169.

Beachy, R. N., Zaitlin, M., Bruening, G. \& Israel, H. W. 1976 A genetic map for the cowpea strain of TMV. Virology 73, 498-507.

Beier, H., Mundry, K. W. \& Issinger, O. G. 1980 In vivo and in vitro translation of the RNAs of four tobamoviruses. Intervirology 14, 292-299.

Best, R. J. 1937 The quantitative estimation of relative concentrations of the viruses of ordinary and yellow tobacco mosaic and of tomato spotted wilt by the primary lesion method. Aust. F. Exp. Biol. Med. Sci. 15, 65-79.

Browning, K. S. \& Clark, J. M. 1980 Translation initiation site of the coat protein messenger ribonucleic acid of the cowpea strain of tobacco mosaic virus. Biochemistry 19, 5922-5926.

Bruening, G., Beachy, R. N., Scalla, R. \& Zaitlin, M. 1976 In vitro and in vivo translation of the ribonucleic acids of a cowpea strain of tobacco mosaic virus. Virology 71, 498-517.

Butler, P. J. G. \& Klug, A. 1971 Assembly of the particle of tobacco mosaic virus from RNA and disks of protein. Nature New Biol. 229, 47-50.
Chen, J., Watanabe, Y., Sako, N., Ohshima, K. \& Okada, Y. 1996 Complete nucleotide sequence and synthesis of infectious in vitro transcripts from a full-length cDNA clone of a rakkyo strain of tobacco mosaic virus. Arch. Virol. 141, 885-900.

Citovsky, V., Knorr, D., Schuster, G. \& Zambryski, P. 1990 The P30 movement protein of tobacco mosaic virus is a singlestrand nucleic acid binding protein. Cell 60, 637-647.

Citovsky, V., Wong, M. L., Shaw, A. L., Prasad, B. V. V. \& Zambryski, P. 1992 Visualization and characterization of tobacco mosaic virus movement protein binding to singlestranded nucleic acids. Plant Cell 4, 397-411.

Crick, F. H. G. 1966 The genetic code-yesterday, today and tomorrow. Cold Spring Harbor Symp. Quant. Biol. 31, 3-9.

Csillery, G., Tobias, I. \& Rusko, J. 1983 A new pepper strain of tomato mosaic virus. Acta Phytopathol. Acad. Sci. Hung. 18, 195-200.

Dawson, W. O., Beck, D. L., Knorr, D. A. \& Grantham, G. L. 1986 cDNA cloning of the complete genome of tobacco mosaic virus and production of infectious transcripts. Proc. Natl Acad. Sci. USA 83, 1832-1836.

Dawson, W. O., Bubrick, P. \& Grantham, G. L. 1988 Modification of the tobacco mosaic virus coat protein gene affecting replication, movement and symptomatology. Phytopathology 78, 783-789.

Deom, C. M., Oliver, M. J. \& Beachy, R. N. 1987 The 30Kkilodalton gene product of tobacco mosaic virus potentiates virus movement. Science 237, 389-394.

Dorokhov, Y. L., Ivanov, P. A., Novikov, V. K., Agranovsky, A. A., Morozov, S. Y., Efimov, V. A., Casper, R. \& Atabekov, J. G. 1994 Complete nucleotide sequence and genome organization of a tobamovirus infecting Cruciferae plants. FEBS Lett. 350, 5-8.

Efron, D. \& Marcus, A. 1973 Translation of TMV-RNA in a cell-free wheat embryo system. Virology 53, 343-348.

Fraenkel-Conrat, H. 1956 The role of the nucleic acid in the reconstitution of active tobacco mosaic virus. 7. Am. Chem. Soc. 78, 882-883.

Fraenkel-Conrat, H. \& Singer, B. 1957 Virus reconstitution. II. Combination of protein and nucleic acid from different strains. Biochim. Biophys. Acta 24, 540-548.

Fraenkel-Conrat, H. \& Williams, R. C. 1955 Reconstitution of active tobacco mosaic virus from its inactive protein and nucleic acid components. Proc. Natl Acad. Sci. USA 41, 690-698.

Fukuda, M., Meshi, T., Okada, Y., Otsuki, Y. \& Takebe, I. 1981 Correlation between particle multiplicity and location on virion RNA of the assembly initiation site for viruses of the tobacco mosaic virus group. Proc. Natl Acad. Sci. USA 78, $4231-4235$.

Funatsu, G. \& Fraenkel-Conrat, H. 1964 Location of amino acid exchanges in chemically evoked mutants of TMV. Biochemistry 3, 1356-1362.

Garcia-Arenal, F. 1988 Sequence and structure at the genome $3^{\prime}$ end of the U2-strain of tobacco mosaic virus, a histidineaccepting tobamovirus. Virology 167, 201-206.

Gierer, A. \& Mundry, K. W. 1958 Production of mutants of tobacco mosaic virus by chemical alteration of its ribonucleic acid in vitro. Nature 182, 1457-1458.

Gierer, A. \& Schramm, G. 1956 Infectivity of ribonucleic acid from tobacco mosaic virus. Nature 177, 702-703.

Goelet, P. \& Karn, J. 1982 Tobacco mosaic virus induces the synthesis of a family of $3^{\prime}$ coterminal messenger RNAs and their complements. F. Mol. Biol. 154, 544-550.

Goelet, P., Lomonossoff, G. P., Butler, P. J. G., Akam, M. E., Gait, M. J. \& Karn, J. 1982 Nucleotide sequence of tobacco mosaic virus RNA. Proc. Natl Acad. Sci. USA 79, 5818-5822.

Guilley, H., Jonard, G. \& Hirth, L. 1975 Sequence of 71 nucleotides of the 3'-end of tobacco mosaic virus RNA. Proc. Natl Acad. Sci. USA 72, 864-868. 
Guilley, H., Jonard, G., Kukla, B. \& Richards, K. E. 1979 Sequence of 1,000 nucleotides at the $3^{\prime}$-end of tobacco mosaic virus RNA. Nucl. Acids Res. 6, 1287-1308.

Harris, J. I. \& Knight, C. A. 1952 Action of carboxypeptidase on tobacco mosaic virus. Nature 170, 613-614.

Hamamoto, H., Sugiyama, Y., Nakagawa, N., Hashida, E., Matsunaga, Y., Takemoto, S., Watanabe, Y. \& Okada, Y. 1993 A new tobacco mosaic virus vector and its use for the systemic production of angiotensin-I-converting enzyme inhibitor in transgenic tobacco and tomato. Bio/Technology 11, 930-932.

Hamamoto, H., Watanabe, Y., Kamada, H. \& Okada, Y. 1997 A single amino acid substitution in the virus-encoded replicase of tomato mosaic tobamovirus alters host specificity. Mol. Plant-Microbe Interact. 10, 1015-1018.

Haseloff, J., Goelet, P., Zimmern, D., Ahlquist, P., Dasgupta, R. \& Kaesberg, P. 1984 Striking similarities in amino acid sequence among nonstructural proteins encoded by RNA viruses that have dissimilar genomic organization. Proc. Natl Acad. Sci. USA 81, 4358-4362.

Heinlein, M., Epel, B. L., Padgett, H. S. \& Beachy, R. N. 1995 Interaction of tobamovirus movement proteins with the plant cytoskeleton. Science 270, 1983-1985.

Hershey, A. D. \& Chase, M. 1952 Independent functions of viral protein and nucleic acid in growth of bacteriophage. 7. Gen. Physiol. 36, 39-56.

Higgins, T. J. V., Goodwin, P. B. \& Whitfeld, P. R. 1976 Occurrence of short particle in beans infected with cowpea strain of TMV. II. Evidence that short particles contain the cistron for coat protein. Virology 71, 486-497.

Holmes, F. O. 1929 Local lesions in tobacco mosaic. Bot. Gaz. 87, 39-55.

Holoubek, V. 1962 Mixed reconsitution between protein from common TMV strain and RNA from different TMV strains. Virology 18, 401-404.

Holt, C. A. \& Beachy, R. N. 1991 In vivo complementation of infectious transcripts from mutant tobacco mosaic virus cDNAs in transgenic plants. Virology 181, 109-117.

Holt, C. A., Hodgson, R. A. J., Coker, F. A., Beachy, R. N. \& Nelson, R. S. 1990 Characterization of the masked strain of tobacco mosaic virus: identification of the region responsible for symptom attenuation by analysis of an infectious cDNA clone. Mol. Plant-Microbe Interact. 3, 417-423.

Hunter, T. R., Hunt, T., Knowland, J. \& Zimmern, D. 1976 Messenger RNA for the coat protein of tobacco mosaic virus. Nature 260, 759-764.

Hunter, T. R., Jackson, R. \& Zimmern, D. 1983 Multiple proteins and subgenomic mRNAs may be derived from single open reading frame on tobacco mosaic virus RNA. Nucl. Acids Res. 11, 801-821.

Hwang, D.-J., Roberts, I. M. \& Wilson, T. M. A. 1994 Expression of tobacco mosaic virus coat protein and assembly of pseudovirus particles in Escherichia coli. Proc. Natl Acad. Sci. USA 91, 9067-9071.

Ikeda, R., Watanabe, E., Watanabe, Y. \& Okada, Y. 1993 Nucleotide sequence of tobamovirus $\mathrm{Ob}$ which can spread systemically in $\mathcal{N}$ gene tobacco. F. Gen. Virology 74, 1939-1944.

Ishikawa, M., Meshi, T., Motoyoshi, F., Takamatsu, N. \& Okada, Y. 1986 In vitro mutagenesis of the putative replicase genes of tobacco mosaic virus. Nucl. Acids Res. 14, 8291-8305.

Jackson, A. O., Zaitlin, M., Siegel, A. \& Francki, R. I. B. 1972 Replication of tobacco mosaic virus. III. Viral RNA metabolism in separated leaf cells. Virology 48, 655-665.

Jonard, G., Richards, K. E., Guilley, H. \& Hirth, L. 1977 Sequence from the assembly nucleation region of TMV RNA. Cell 11, 483-493.

Joshi, S., Pleij, G. W. A., Haenni, A. L., Chapeville, F. \& Bosch, L. 1983 Properties of the tobacco mosaic virus intermediate length RNA-2 and its translocation. Virology 127, 100-111.
Kamer, G. \& Argos, P. 1984 Primary structural comparison of RNA-dependent polymerases from plant, animal and bacterial viruses. Nucl. Acids Res. 12, 7269-7282.

Kasteel, D. T. J., van der Wel, N. N., Jansen, K. A. J., Goldbach, R. W. \& van Lent, J. W. M. 1997 Tubule-forming capacity of the movement protein of alfalfa mosaic virus and brome mosaic virus. F. Gen. Virol. 78, 2089-2093.

Kawakami, S., Padgett, H. S., Hosokawa, D., Okada, Y., Beachy, R. N. \& Watanabe, Y. 1998 Significance of serine at codon 37 in the movement protein of tomato mosaic tobamovirus for phosphorylation, intracellular localization of the protein, stability in vivo and cell-to-cell movement function. $\mathcal{F}$. Virol. (Submitted.)

Keith, J. \& Fraenkel-Conrat, H. 1975 Tobacco mosaic virus RNA carries 5'-terminal triphosphorylated guanosine blocked by 5'-linked 7-methylguanosine. FEBS Lett. 57, 31-33.

Kikkert, M., van Poelwijk, F., Storms, M., Kassies, W., Bloksma, H., van Lent, J., Kormelink, R. \& Goldbach, R. 1997 A protoplast system for studying tomato spotted wilt virus infection. 7. Gen. Virol. 78, 1755-1763.

Kirita, M., Akutsu, K., Watanabe, Y. \& Tsuda, S. 1997 Nucleotide sequence of the Japanese isolate of pepper mild mottle tobamovirus RNA. Ann. Phytopathol. Soc. Fapan 63, 373-376.

Knorr, D. A. \& Dawson, W. O. 1988 A point mutation in the tobacco mosaic virus capsid protein gene induces hypersensitivity in Nicotiana sylvestris. Proc. Natl Acad. Sci. USA 85, 170-174.

Knowland, J. 1974 Protein synthesis directed by the RNA from a plant virus in a normal animal cell. Genetics 78, 383-394.

Knowland, J., Hunter, T., Hunt, T. \& Zimmern, P. 1975 Translation of tobacco mosaic virus RNA and isolation of the messenger for TMV coat protein. Colloq. Inst. Natl Sante Rech. Med. 47, 211-216.

Kumagai, M. H. (and 11 others) 1993 Rapid, high-level expression of biologically active $\alpha$-trichosanthin in transfected plants by an RNA viral vector. Proc. Natl Acad. Sci. USA 90, 427-430.

Lamy, D., Jonard, G., Guilley, H. \& Hirth, L. 1975 Comparison between the $3^{\prime} \mathrm{OH}$ end RNA sequence of two strains of tobacco mosaic virus which may be aminoacylated. FEBS Lett. 60, 202-204.

Lartey, R. T., Lane, L. C. \& Melcher, U. 1994 Electron microscopic and molecular characterization of turnip vein-clearing virus. Arch. Virol. 138, 287-298.

Lebeurier, G., Nicolaieff, A. \& Richards, K.E. 1977 Inside-out model for self-assembly of tobacco mosaic virus. Proc. Natl Acad. Sci. USA 74, 149-153.

Lehto, K., Grantham, G. L. \& Dawson, W. O. 1990 Insertion of sequence containing the coat protein subgenomic RNA promoter and leader in front of the tobacco mosaic virus $30 \mathrm{~K}$ ORF delays its expression and causes defective cell-to-cell movement. Virology 174, 145-157.

McLean, B. G., Zupen, J. \& Zambryski, P. C. 1995 Tobacco mosaic virus movement protein associates with the cytoskeleton in tobacco cells. Plant Cell 7, 2101-2114.

Mandeles, S. 1968 Location of unique sequences in tobacco mosaic virus ribonucleic acid. 7. Biol. Chem. 243, 3671-3674.

Markham, R. \& Smith, K. M. 1949 Studies on the virus of turnip yellow mosaic. Parasitology 39, 330-342.

Maxam, A. M. \& Gilbert, W. 1977 A new method for sequencing DNA. Proc. Natl Acad. Sci. USA 74, 560-564.

Meshi, T., Ohno, T., Iba, H. \& Okada, Y. 1981 Nucleotide sequence of a cloned cDNA copy of TMV (cowpea strain) RNA, including the assembly origin, the coat protein cistron, and the 3' non-coding region. Mol. Gen. Genet. 184, 20-25. 
Meshi, T., Ohno, T. \& Okada, Y. $1982 a$ Nucleotide sequence and its character of cistron coding for the $30 \mathrm{~K}$ protein of tobacco mosaic virus (OM strain). F. Biochem. 91, 1441-1444.

Meshi, T., Takamatsu, N., Ohno, T. \& Okada, Y. 1982b Molecular cloning of the complementary DNA copies of the common and cowpea strains of tobacco mosaic virus RNA. Virology 118, 64-75.

Meshi, T., Ishikawa, M., Takamatsu, N., Ohno, T. \& Okada, Y. $1983 a$ The 5 '-terminal sequence of TMV RNA. Question on the polymorphism found in vulgare strain. FEBS Lett. 162, 282-285.

Meshi, T., Kiyama, R., Ohno, T. \& Okada, Y. $1983 b$ Nucleotide sequence of the coat protein cistron and the $3^{\prime}$ noncoding region of cucumber green mottle mosaic virus RNA. Virology 127, 54-64.

Meshi, T., Ishikawa, M., Motoyoshi, F., Semba, K. \& Okada, Y. 1986 In vitro transcription of infectious RNAs from full-length cDNAs of tobacco mosaic virus. Proc. Natl Acad. Sci. USA 83, 5043-5047.

Meshi, T., Watanabe, Y., Saito, T., Sugimoto, A., Maeda, T. \& Okada, Y. 1987 Function of the 30kd protein of tobacco mosaic virus: involvement in cell-to-cell movement and dispensability for replication. EMBO 7. 6, 2557-2563.

Meshi, T., Motoyoshi, F., Adachi, A., Watanabe, Y., Takamatsu, N. \& Okada, Y. 1988 Two concomitant base substitutions in the putative replicase genes of tobacco mosaic virus confer the ability to overcome the effects of a tomato resistance gene Tm-1. EMBO 7. 7, 1575-1581.

Meshi, T., Motoyoshi, F., Maeda, T., Yoshiwoka, S., Watanabe, H \& Okada, Y. 1989 Mutations in the tobacco mosaic virus $30-\mathrm{kD}$ protein gene overcome $T m-2$ resistance in tomato. Plant Cell 1, 515-522.

Mundry, K. W., Watkins, P. A. G., Ashfield, T., Plaskitt, K. A., Eisele-Walter, S. \& Wilson, T. M. A. 1991 Complete uncoating of the $5^{\prime}$ leader sequence of tobacco mosaic virus RNA occurs rapidly and is required to initiate cotranslational virus disassembly in vitro. F. Gen. Virol. 72, 769-777.

Nishiguchi, M., Motoyoshi, F. \& Oshima, N. 1978 Behaviour of a temperature sensitive strain of tobacco mosaic virus in tomato leaves and protoplasts. 7. Gen. Virol. 39, 53-61.

Nishiguchi, M., Kikuchi, S., Kiho, Y., Ohno, T., Meshi, T. \& Okada, Y. 1985 Molecular basis of plant viral virulence: the complete nucleotide sequence of an attenuated strain of tobacco mosaic virus. Nucl. Acids Res. 13, 5585-5590.

Oberg, B. \& Philipson, L. 1972 Binding of histidine to tobacco mosaic virus RNA. Biochem. Biophys. Res. Commun. 48, 927-932.

Ohno, T., Nozu, Y. \& Okada, Y. 1971 Polar reconstitution of tobacco mosaic virus. Virology 44, 510-516.

Ohno, T., Okada, Y., Shimotono, K., Miura, K., Shinshi, H., Miwa, M. \& Sugimura, T. 1976 Enzymatic removal of the 5 terminal methylated blocked structure of tobacco mosaic virus RNA and its effects on infectivity and reconstitution with coat protein. FEBS Lett. 67, 209-213.

Ohno, T., Takamatsu, N., Meshi, T., Okada, Y., Nishiguchi, M. \& Kiho, Y. 1983 Single amino acid substitution in 30K protein of TMV defective in virus transport function. Virology 131, 255-258.

Ohno, T., Aoyagi, M., Yamanashi, Y., Saito, H., Ikawa, S., Meshi, T. \& Okada, Y. 1984 Nucleotide sequence of the tobacco mosaic virus (tomato strain) genome and comparison with the common strain genome. F. Biochem. 96, 1915-1923.

Okada, Y. 1986 Molecular assembly of tobacco mosaic virus in vitro. Adv. Biophys. 22, 95-149.

Okamoto, S. Machida, Y. \& Takebe, I. 1988 Subcellular localization of tobacco mosaic virus minus strand RNA in infected protoplasts. Virology 167, 194-200.

Osman, T. A. M. \& Buck, K. W. 1997 The tobacco mosaic virus RNA polymerase complex contains a plant protein related to the RNA-binding subunit of yeast eIF-3. F. Virol. 71, 6075-6082.

Otsuki, Y., Takebe, I., Ohno, T., Fukuda, M. \& Okada, Y. 1977 Reconstitution of tobacco mosaic virus rods occurs bidirectionally from an internal intiation region: demonstration by electron microscopic serology. Proc. Natl Acad. Sci. USA 74, 1913-1917.

Padgett, H. S. \& Beachy, R. N. 1993 Analysis of a tobacco mosaic virus strain capable of overcoming $\mathcal{N}$-mediated resistance. Plant Cell 15, 577-586.

Palukaitis, P., Garcia-Arenal, F., Sulzinski, M. A. \& Zaitlin, M. 1983 Replication of tobacco mosaic virus. Further characterization of single and double stranded virus-related RNAs from TMV infected plants. Virology 131, 533-545.

Pelham, H. R. B. 1978 Leaky UGA termination codon in tobacco mosaic virus RNA. Nature 272, 469-471.

Pelham, H. R. B. \& Jackson, R. J. 1976 An efficient mRNAdependent translation system from reticulocyte lysates. Eur. $\mathcal{f}$. Biochem. 67, 247-256.

Perham, R. N. \& Wilson, T. M. A. 1976 The polarity of stripping of coat protein subunits from the RNA in tobacco mosaic virus under alkaline conditions. FEBS Lett. 62, 11-15.

Pleij, C. W. A., Rietvelt, K. \& Bosch, L. 1985 A new principle of RNA folding based on pseudoknotting. Nucl. Acids Res. 13, 1717-1731.

Richards, K. E., Guilley, H. A., Jonard, G. \& Hirth, L. 1978 Nucleotide sequence at the 5 '-extremity of tobacco mosaic virus RNA. Eur. 7. Biochem. 84, 513-519.

Rietveld, K., Linschooten, K., Pleij, C. W. A. \& Bosch, L. 1984 The three-dimensional folding of the tRNA-like structure of tobacco mosaic virus RNA. EMBO F. 3, 2613-2619.

Saito, T., Watanabe, Y., Meshi, T. \& Okada, Y. 1986 Preparation of antibodies that react with the large non-structural proteins of tobacco mosaic virus by using Escherichia coli expressed fragments. Mol. Gen. Genet. 205, 82-89.

Saito, T., Meshi, T., Takamatsu, N. \& Okada, Y. 1987 Coat protein gene sequence of tobacco mosaic virus encodes a host response determinant. Proc. Natl Acad. Sci. USA 84, 6074-6077.

Saito, T., Yamanaka, K., Watanabe, Y., Takamatsu, N., Meshi, T. \& Okada, Y. 1989 Mutational analysis of the coat protein gene of tobacco mosaic virus in relation to hypersensitivity response in tobacco plants with the $\mathcal{N}^{\prime}$ gene. Virology 173, 11-20.

Saito, T., Yamanaka, K. \& Okada, Y. 1990 Long-distance movement and viral assembly of tobacco mosaic virus mutants. Virology 176, 329-336.

Sakai, F. \& Takebe, I. 1974 Protein synthesis in tobacco mesophyll protoplasts induced by tobacco mosaic infection. Virology 62, 426-433

Sanger, F., Nicklen, S. \& Coulson, A. R. 1977 DNA sequencing with chain-terminating inhibitors. Proc. Natl Acad. Sci. USA 74, 5463-5467.

Scalla, R., Boudon, E. \& Rigaud, J. 1976 Sodium dodecyl sulphate-polyacrylamide gel electrophoretic detection of two high molecular weight proteins associated with tobacco mosaic virus infection in tobacco. Virology 69, 339-345.

Schwartz, J. H. 1967 Initiation of protein synthesis under the direction of tobacco mosaic virus RNA in cell-free extracts of Escherichia coli. 7. Mol. Biol. 30, 309-322.

Shaw, J. G., Plaskitt, K. A. \& Wilson, T. M. A. 1986 Evidence that tobacco mosaic virus particles disassemble cotranslationally in vivo. Virology 148, 326-336.

Siegel, A., Zaitlin, M. \& Sehgal, O. P. 1962 The isolation of defective tobacco mosaic virus strains. Proc. Natl Acad. Sci. USA 48, 1845-1851.

Siegel, A., Hari, V., Montgomery, I. \& Kolacz, K. 1976 A messenger RNA for capsid protein isolated from tobacco mosaic virus-infected tissue. Virology 73, 363-371. 
Skotnicki, A., Gibbs, A. \& Shaw, D.C. 1976 In vitro translation of polyribosome-associated RNAs from tobamovirus-infected plants. Intervirology 7, 256-271.

Smith, H. O. \& Wilcox, K. W. 1970 A restriction enzyme from Haemophilus influenzae. I. Purification and general properties. 7. Mol. Biol. 51, 379-391.

Solis, I. \& Garcia-Arenal, F. 1990 The complete nucleotide sequence of the genomic RNA of the tobamovirus tobacco mild green mosaic virus. Virology 177, 553-558.

Stanley, W. M. 1934 Chemical studies on the virus of tobacco mosaic. II. The proteolytic action of pepsin. Phytopathology 24, 1269-1289.

Stanley, W. M. 1935 Isolation of a crystalline protein possessing the properties of tobacco mosaic virus. Science $\mathbf{8 1}$, 644-645.

Stanley, W. M. 1937 Chemical studies on the virus of tobacco mosaic. VIII. The isolation of a crystalline protein possessing the properties of aucuba mosaic virus. 7. Biol. Chem. 117, 325-340.

Steinschneider, A. \& Fraenkel-Conrat, H. 1966 Studies of nucleotide sequences in tobacco mosaic virus ribonucleic acid. III. Periodate oxidation and semicarbazone formation. Biochemistry 5, 2729-2734.

Sugiyama, T. \& Fraenkel-Conrat, H. 1961 Identification of 5'linked adenosine as end group of TMV-RNA. Proc. Natl Acad. Sci. USA 47, 1393-1397.

Sugiyama, T. \& Fraenkel-Conrat, H. 1963 The end-groups of tobacco mosaic virus RNA. II. Nature of the 3'-linked chain end in TMV and of both ends in four strains. Biochemistry 2, 332-334.

Sugiyama, Y., Hamamoto, H., Takemoto, S., Watanabe, Y. \& Okada, Y. 1995 Systemic production of foreign peptides on the particle surface of tobacco mosaic virus. FEBS Lett. 359, 247-250.

Sulzinski, M. A., Gabard, K. A., Palukaitis, P. \& Zaitlin, M. 1985 Replication of tobacco mosaic virus. VIII. Characterization of a third subgenomic TMV RNA. Virology 145, 132-140.

Sumner, J. B. 1926 The isolation and crystallisation of the enzyme urease. 7. Biol. Chem. 69, 435-441.

Takahashi, T., Okuda, S., Natsuaki, T., Watanabe, Y. \& Okada, Y. 1998 The movement protein of tomato mosaic tobamovirus induces tubular structures in protoplasts. (In preparation.)

Takamatsu, N., Ohno, T., Meshi, T. \& Okada, Y. 1983 Molecular cloning and nucleotide sequence of the $30 \mathrm{~K}$ and the coat protein cistron of TMV (tomato strain) genome. Nucl. Acids Res. 11, 3767-3778.

Takamatsu, N., Ishikawa, M., Meshi, T. \& Okada, Y. 1987 Expression of bacterial chloramphenicol acetyltransferase gene in tobacco plants mediated by TMV-RNA. EMBO F. 6 , 307-311.

Takamatsu, N., Watanabe, Y., Meshi, T. \& Okada, Y. 1990 Mutational analysis of the pseudoknot region in the $3^{\prime}$ noncoding region of tobacco mosaic virus RNA. 7. Virol. 64, 3686-3693.

Takamatsu, N., Watanabe, Y., Iwasaki, T., Shiba, T., Meshi, T. \& Okada, Y. 1991 Deletion analysis of the $5^{\prime}$ untranslated leader sequence of tobacco mosaic virus RNA. 7. Virol. 65, 1619-1622.

Taliansky, M. E., Malyshenko, S. I., Pshennikova, E. S., Kaplan, I. B., Ulanova, E. F. \& Atabekov, J. G. 1982 Plant virus-specific transport function. I. Virus genomic control required for systemic spread. Virology 122, 318-326.

Temin, H. M. \& Mizutani, S. 1970 RNA-dependent DNA polymerase in virions of Rous sarcoma virus. Nature 226, $1211-1213$
Tobias, I., Rast, A. T. B. \& Maat, D. Z. 1982 Tobamoviruses of pepper, eggplant, and tobacco. Comparative host reaction and serological relationships. Neth. 7. Plant Pathol. 88, 257-268.

Tomenius, K., Clapham, D. \& Meshi, T. 1987 Localization by immunogold cytochemistry of the virus-coded $30 \mathrm{~K}$ protein in plasmodesmata of leaves infected with tobacco mosaic virus. Virology 160, 363-371.

Tsugita, A. \& Fraenkel-Conrat, H. 1960 The amino acid composition and $\mathrm{C}$-terminal sequence of a chemically evoked mutant of tobacco mosaic virus. Proc. Natl Acad. Sci. USA 46, 636-642.

Tsugita, A. \& Fraenkel-Conrat, H. 1962 The composition of the proteins of chemically evoked mutants of TMV-RNA. 7. Mol. Biol. 4, 73-82.

Tsugita, A., Fraenkel-Conrat, H., Nirenberg, M. W. \& Matthei, J. H. 1962 Demonstration of the messenger role of viral RNA. Proc. Natl Acad. Sci. USA 48, 846-853.

Turpen, T. H., Reinl, S. T., Charoenvit, Y., Hoffman, S. L., Fallarme, V. \& Grill, L. K. 1995 Malarial epitopes expressed on the surface of recombinant tobacco mosaic virus. Bio/ Technology 13, 53-57.

Ugaki, M. (and 8 others) 1991 The nucleotide sequence of cucumber green mottle mosaic (SH strain) genomic RNA. 7. Gen. Viol. 72, 1487-1495.

Van Belkum, A., Abrahams, J. P., Pleij, C. W. A. \& Bosch, L. 1985 Five pseudoknots are present at the 204 nucleotides long $3^{\prime}$ noncoding region of tobacco mosaic virus RNA. Nucl. Acids Res. 13, 7673-7686.

Van Lent, J., Storms, M., Van der Meer, F., Wellink, J. \& Goldbach, R. 1991 Tubular structures involved in movement of cowpea mosaic virus are also formed in infected cowpea protoplasts. 7. Gen. Virol. 72, 2615-2623.

Watanabe, Y., Emori, Y., Ooshika, I., Meshi, T., Ohno, T. \& Okada, Y. 1984a Synthesis of TMV-specific RNAs and proteins at the early stage of infection in tobacco protoplasts: transient expression of the $30 \mathrm{~K}$ protein and its mRNA. Virology 133, 18-24.

Watanabe, Y., Meshi, T. \& Okada, Y. $1984 b$ The initiation site for transcription of the TMV $30-\mathrm{kDa}$ protein messenger RNA. FEBS Lett. 173, 247-250.

Watanabe, Y., Meshi, T. \& Okada, Y. 1987a Infection of tobacco protoplasts with in vitro transcribed tobacco mosaic virus RNA using an improved electroporation method. FEBS Lett. 219, 65-69.

Watanabe, Y., Morita, N., Nishiguchi, M. \& Okada, Y. $1987 b$ Attenuated strains of tobacco mosaic virus: reduced synthesis of a viral protein with a cell-to-cell movement function. $\mathcal{F}$. Mol. Biol. 194, 699-704.

Watanabe, Y., Ogawa, T. \& Okada, Y. 1992 In vivo phosphorylation of the $30-\mathrm{kDa}$ protein of tobacco mosaic virus. FEBS Lett. 313, 181-184.

Watanabe, Y., Ohnishi, J., Saitoh, H., Hosokawa, D. \& Okada, Y. 1996 Addition of nucleotides similar to deleted CAA repeats in the $5^{\prime}$ non-coding region of tomato mosaic virus RNA following propagation. 7. Gen. Virol. 77, 2353-2357.

Weber, H., Schultze, S. \& Pfitzner, A. J. P. 1993 Two amino acid substitutions in the tomato mosaic virus 30-kilodalton movement protein alter the ability to overcome the $T m-2^{2}$ resistance gene in the tomato. F. Virol. 87, 6432-6438.

Whitham, S., Dinesh-Kumar, S. P., Choi, D., Hehl, R., Corr, C. \& Baker, B. 1994 The product of the tobacco mosaic virus resistance gene $\mathcal{N}$ : similarity to Toll and interleukin-I receptor. Cell 78, 1101-1115.

Wilson, T. M. A. 1984 Cotranslational disassembly of tobacco mosaic virus in vitro. Virology 137, 255-265. 
Wittmann, H. G. \& Wittmann-Liebold, B. 1966 Protein chemical studies of two RNA viruses and their mutants. Cold Spring Harbor Symp. Quant. Biol. 31, 163-172.

Wolf, S., Deom, C. M., Beachy, R. N. \& Lucas, W. J. C. 1989 Movement protein of tobacco mosaic virus modifies plasmodesmatal size exclusion limit. Science 246, 377-379.

Wu, X., Xu, Z. \& Shaw, J. G. 1994 Uncoating of tobacco mosaic virus RNA in protoplasts. Virology 137, 255-265.

Yamanaka, T., Komatani, H., Meshi, T., Naito, S., Ishikawa, M. \& Ohno, T. 1998 Complete nucleotide sequence of the genomic RNA of tobacco mosaic virus strain Cg. Virus Genes 16, 173-176.

Zimmern, D. 1975 The 5'-end group of tobacco mosaic virus RNA is m7GpppGp. Nucl. Acids Res. 2, 1189-1201.

Zimmern, D. 1977 The nucleotide sequence at the origin for assembly on tobacco mosaic virus RNA. Cell, 11, 463-482.

Zimmern, D. \& Wilson, T. M. A. 1976 Location of the origin for viral reassembly on tobacco mosaic virus RNA and its relation to stable fragment. Lett FEBS. 71, 294-298. 


\section{Errata to volume 354}

Phil. Trans. R. Soc. Lond. B 354, 417-433 (February 1999)

\section{Algal morphogenesis: modelling interspecific variation in Micrasterias with reaction-diffusion patterned catalysis of cell surface growth}

David M. Holloway and Lionel G. Harrison

On page 417, the footnotes indicated by the asterisk and dagger were mistakenly reversed. D. M. Holloway has moved to the British Columbia Institute of Technology and L. G. Harrison is the author for correspondence.

In the abstract (p. 417) it should have read L. G. Harrison and not D. M. Harrison.

Phil. Trans. R. Soc. Lond. B 354, 569-582 (March 1999)

Historical overview of research on the tobacco mosaic virus genome: genome organization, infectivity and gene manipulation

Y. Okada

In the abstract (p. 569) mitochondrial DNA was incorrectly printed instead of mRNA. The complete, corrected sentence is reproduced below.

Early in the development of molecular biology, TMV RNA was widely used as a mRNA that could be purified easily, and it contributed much to research on protein synthesis.

Phil. Trans. R. Soc. Lond. B 354, 1325-1346 (July 1999)

Spatial attention and neglect: parietal, frontal and cingulate contributions to the mental representation and attentional targeting of salient extrapersonal events

M.-Marsel Mesulam

In the legend to figure 3 (p.1332), the words left and right were mistakenly transposed. The complete, corrected sentence is reproduced below.

The arrows depict the directional probability of attentional shifts and representational salience, orange for the right hemisphere, purple for the left hemisphere. 